$\xi_{p}$

\title{
A Review on Water Footprint Assessment and Water-Food- Energy Nexus for Electronic and Food Products
}

\author{
P.X.H. Bong ${ }^{1}$, M.A. Malek ${ }^{2}$, Z.Z. Noor ${ }^{3}$ \\ ${ }^{l}$ Department of Civil Engineering, Universiti Tenaga Nasional, Malaysia \\ ${ }^{2}$ Institute of Power Energy (IPE), Universiti Tenaga Nasional, Malaysia \\ ${ }^{3}$ Centre for Environmental Sustainability and Water Security, Universiti Teknologi Malaysia \\ *Corresponding Author E mail: pbxh045138@gmail.com
}

\begin{abstract}
Water Footprint Assessment (WFA) has emerged as a new interdisciplinary field of study, that specialize in the study of water use, scarcity, and pollution, in respect to production, consumption, and trade of water-intensive products and services. It consists of the analysis of various techniques and practices, policy plans, and governance mechanisms that contributed to the rise of sustainability, efficiency, and equitability of water footprints. This study focuses on WFA specifically for electronic and food manufacturing products. It determined contributions of different players namely the governments, companies, investors and civil society. This study typically reviews water use in relation to demand for electronic products, food and energy used. It appraisals the sustainable water use translated into coherent food, energy, incentives and trade policies. Water-Food-Energy (WFE) nexus from the perspective of electronic and food manufacturing products are also reviewed. In this study, the challenges in estimating water footprints and WFE nexus for electronics and food manufacturing products include the understanding of various levels of demand, geographical, temporal variations, assessment of uncertainties involved, and the assessment of water-footprint related problems and solutions. The outcomes showed that combining several methods of WFA can obtain adequate results for the water footprint accounting. The WFE nexus is preferred to use life-cycle assessment (LCA) method to identify the environmental impacts. The significances of this study are to raise the awareness on water usage in the supply chain process of the electronic and food products then recommend good practices in water usage.
\end{abstract}

Keywords: Water Footprint Assessment; Water-Food-Energy Nexus; Electronic; Food; water use, scarcity; pollution

\section{Introduction}

Water act as a foundation as it is necessary to life. Almost all aspects of life are influenced by water such as products, food and energy. Water consumption is expected to be increased by $55 \%$ in between 2000 and 2050, especially because of the increasing of water need from thermal electricity generation and manufacturing [1]. Human needs water to survive and to enhance their live. In other words, human cannot survive without water. Currently, scarcity of water is the main issues in the world. Human activities that resulted to waste and pollutants have impacted large volume of water worldwide. At the global scale, large portion of water is utilized in agricultural sector. However, there are also substantial water volumes used and polluted in manufacturing of electronics and food sectors. For examples, the total water footprint of cement plant located on western Iran is $3.614 \times 10^{6} \mathrm{~m}^{3}$ in 2016 which indicating the risk of surviving in dry seasons [2] and the WF of fat-and-protein corrected milk (FPCM) production at Irish was at an average of $690 \mathrm{~L}$ water $/ \mathrm{kg}$ [3]. These showed that the concern needs to decrease the water footprint is urgent.

The objective of this paper is to review previous studies based on the WFA and WFE nexus, which focus on the electronic and food productions. The results of this review paper can be beneficial for policy makers and stakeholders specifically, to comprehend the usefulness of water footprints indicator in addition to advance guidelines and/or international decisions able to better the fresh- water usage also to draft legislation on water footprint sustainable consumption. The importance is to make contribution towards the understanding of life cycle assessment in water resources management.

\section{Water Footprint Assessment}

Water Footprint Assessment (WFA) is a new analytical method that provides a new perspective to develop an adaptable technique of water management for products, processes, or organizations $[4,5]$.

At present, some approaches have been reported for WFA [4,6]. The Water Footprint Network (WFN) developed one of the approaches that focuses on calculating green, blue and grey water, determine sustainability assessments, and evaluating the response formulation $[3,4,7]$. WFN has developed water footprint accounting and assessment for volumetric measurement of water consumption and pollution, but not on the Life Cycle Analyses (LCA) for environmental impact $[4,8]$. Other than WFN, International Standard Organization (ISO) 14046 standardization work for WF was introduced in 2010. The purpose is to enhance harmonization of terminology and framework [9].

\subsection{Water Footprint Assessment for Electronic Products}

This section described various available models on WFA in manufacturing of electronic products. However, most of the published 
studies on footprint obtained from manufacturing of electronic products are related to carbon footprint. Therefore, the ensuing section presents studies conducted on WFA for almost similar types of industrial products.

\subsubsection{Water Footprint Assessment on Industrial Products}

Gerbens-leenes, Hoekstra, and Bosman (2018) [9] assessed blue and grey water footprints (WF) for five construction materials: unalloyed steel, chromium-nickel unalloyed steel, soda-lime glass, Portland cement (CEM I) and Portland composite cement (CEM II/B). This study showed that the relationship between blue WF and energy consumption is important in the total blue WF used to produce the construction materials. The production of these materials is energy demanding and includes high electricity usage.

Hosseinian and Nezamoleslami (2018) [2] suggested a comprehensive model named system boundary analysis, to determine WF of cement production based on type of energy used, human effects and transportation located at Western Iran. The study presented total WF of certain cement plant at $3.614 \times 10^{6} \mathrm{~m}^{3}$ in year 2016 with water consumption amounting to $2.162 \mathrm{~m}^{3}$ for each ton of cement production. The virtual water consumption of certain cement plant is concluded to contribute to $90 \%$ of the total WF.

Shaikh et al. (2017) [10] developed a decision support tool for WF analysis to evaluate the present and future trend of water consumption and withdrawal by the electricity production sectors in Turkish. The study showed that the future average water consumption from the Official Governmental Plan energy mix in year 2030 is forecasted to be around $8.1 \%$ and $9.6 \%$ fewer than that of the Business-As-Usual and Renewable Energy-Focused Development Plan scenarios, respectively. As a result, the water is consumed substantially even by the renewable resources.

Schyns, Booij and Hoekstra (2017) [11] presented the first estimation of global water consumption related to round wood production for lumber, pulp, paper, fuel and firewood. The results showed that the global water consumption attributed to round wood production has risen from $768 \times 10^{9} \mathrm{~m}^{3} / \mathrm{y}$ in 1961-1970 to $961 \times 10^{9} \mathrm{~m}^{3} / \mathrm{y}$ in $2001-2010$. The results of this study contributed to the overall picture of water and energy consumption in wood manufacturing.

Musikavong and Gheewala (2016) [12] evaluated water scarcity footprints (WSF) of ribbed smoked sheet (RSS) and RSS bales located at southern Thailand. The results showed that water consumption for RSS and RSS bales were 549 and $592 \mathrm{~m}^{3} /$ tones respectively. The difference of water consumption between production of RSS and RSS bales to rubber plantation was found to be very small. It is also mentioned that values of WSF and water consumption are required to be included as indicators to decide the appropriate location for rubber plantation.

Scherer and Stephan (2016) [13] calculated WF at 1500 numbers of hydropower plants in order to enhance the quantify exercises on water consumption. The results showed that the previous studies of WFA on hydropower are mostly overvalued from the impacts of hydropower to water scarcity. The flow alterations typically effected the environment more than the water consumption. Since impacts generally varies among hydropower plants where plantspecific evaluations are necessary.

$\mathrm{Gu}$ et al. (2015) [14] proposed the system boundary analysis method to exploit general and useful industry methodology on WFA. The case study used was the iron and steel industry company located at Eastern China. For a better understanding, the blue and grey WFs are calculated separately. The results showed that the blue WF was at $2.44 \times 10^{7} \mathrm{~m}^{3}$ and the grey WF was at $6.5 \mathrm{x}$ $10^{8} \mathrm{~m}^{3}$.

Based on study by Berger et al. (2014) [15], the water accounting and vulnerability evaluation (WAVE) model is presented to improve the analysis of water consumption that resulted in numerous outcomes along the product's supply chain. This is the first time that the atmospheric evaporation recycling within the drainage basins was considered at the accounting level in order to decrease up to $32 \%$ of water usage volumes. The results showed that WAVE will facilitate to understand values of volumetric WF and promote a sustainability use of global freshwater resources.

Berger et al. (2012) [16] analyzed water consumption and the resulting impacts to Volkswagens car models such as Passat, Polo, and Golf. It shows the primary application of impact-oriented WF methods in complex industrial products. The results showed that water usage along the life cycles of 3 cars is between from 52 to $83 \mathrm{~m}^{3} / \mathrm{car}$, of which greater than $95 \%$ is used in the manufacture stage. Results also showed that the water usage in 43 countries worldwide where only $10 \%$ is used directly at Volkswagens production sites.

\subsubsection{Summary of Water Footprint Assessment on Industrial Products}

Table 1: Summary of water footprint assessment on industrial products

\begin{tabular}{|c|c|c|c|c|}
\hline $\begin{array}{c}\text { Authors, } \\
\text { year, country }\end{array}$ & Product & Method & $\begin{array}{c}\text { Compo- } \\
\text { nent }\end{array}$ & Outcomes \\
\hline $\begin{array}{c}\text { Gerbens- } \\
\text { leenes, } \\
\text { Hoekstra, } \\
\text { and Bosman } \\
(2018)\end{array}$ & $\begin{array}{l}\text { Steel, ce- } \\
\text { ment and } \\
\text { glass }\end{array}$ & $\begin{array}{c}\text { Life Cycle } \\
\text { Assess- } \\
\text { ment } \\
\text { (LCA) and } \\
\text { WF ac- } \\
\text { counting } \\
\text { by Water } \\
\text { Footprint } \\
\text { Network } \\
\text { (WFN) }\end{array}$ & $\begin{array}{l}\text { Blue and } \\
\text { grey WFs }\end{array}$ & $\begin{array}{l}\text { Methods, } \\
\text { tools and } \\
\text { data from } \\
\text { LCA and } \\
\text { WFN can } \\
\text { efficiently be } \\
\text { combined. }\end{array}$ \\
\hline $\begin{array}{c}\text { Hosseinian } \\
\text { and } \\
\text { Nezamolesla } \\
\text { mi } \\
(2018) \\
\text { Iran }\end{array}$ & Cement & $\begin{array}{c}\text { System } \\
\text { boundary } \\
\text { analysis }\end{array}$ & $\begin{array}{l}\text { Blue and } \\
\text { grey WFs }\end{array}$ & $\begin{array}{l}\text { A compre- } \\
\text { hensive } \\
\text { model is } \\
\text { proposed to } \\
\text { assess WF } \\
\text { for cement } \\
\text { production. }\end{array}$ \\
\hline $\begin{array}{c}\text { Shaikh, } \\
\text { Kucukvar, } \\
\text { Cihat, and } \\
\text { Kirkil } \\
\text { (2017) } \\
\text { Turkish }\end{array}$ & Electricity & $\begin{array}{c}\text { Decision } \\
\text { support } \\
\text { tool }\end{array}$ & $\begin{array}{l}\text { Blue and } \\
\text { grey WF }\end{array}$ & $\begin{array}{l}\text { A decision } \\
\text { support tool } \\
\text { is developed } \\
\text { to forecast } \\
\text { the water } \\
\text { consumption } \\
\text { and with- } \\
\text { drawal of } \\
\text { electricity } \\
\text { production } \\
\text { sectors. }\end{array}$ \\
\hline $\begin{array}{c}\text { Schyns, } \\
\text { Booij, and } \\
\text { Hoekstra } \\
(2017)\end{array}$ & $\begin{array}{l}\text { Lumber, } \\
\text { pulp, paper, } \\
\text { fuel and } \\
\text { firewood }\end{array}$ & WFA & $\begin{array}{l}\text { Blue and } \\
\text { green } \\
\text { WFs }\end{array}$ & $\begin{array}{l}\text { The first } \\
\text { approxima- } \\
\text { tion of the } \\
\text { global water } \\
\text { consumption } \\
\text { in the forest- } \\
\text { ry sector } \\
\text { linked to } \\
\text { roundwood } \\
\text { production is } \\
\text { provided. }\end{array}$ \\
\hline $\begin{array}{c}\text { Musikavong } \\
\text { and } \\
\text { Gheewala } \\
(2016) \\
\text { Southern } \\
\text { Thailand }\end{array}$ & $\begin{array}{c}\text { Ribbed } \\
\text { smoked } \\
\text { sheet }\end{array}$ & $\begin{array}{c}\text { System } \\
\text { boundary } \\
\text { analysis } \\
\text { method }\end{array}$ & $\begin{array}{c}\text { Water } \\
\text { scarcity } \\
\text { footprint }\end{array}$ & $\begin{array}{l}\text { The water } \\
\text { scarcity } \\
\text { footprint in } \\
\text { terms of } \\
\text { water depri- } \\
\text { vation is } \\
\text { identified. }\end{array}$ \\
\hline $\begin{array}{c}\text { Scherer and } \\
\text { Stephan } \\
(2016) \\
\text { World }\end{array}$ & Hydropower & & $\begin{array}{l}\text { Blue and } \\
\text { grey WFs }\end{array}$ & $\begin{array}{l}\text { Enhance the } \\
\text { method for } \\
\text { WFA of } \\
\text { hydropower } \\
\text { by using } \\
\sim 1500 \text { hy- } \\
\text { dropower } \\
\text { plants. }\end{array}$ \\
\hline $\begin{array}{c}\text { Gu, Xu, } \\
\text { Keller, Yuan, } \\
\text { Li, Zhang, }\end{array}$ & $\begin{array}{l}\text { Iron and } \\
\text { steel }\end{array}$ & $\begin{array}{l}\text { System } \\
\text { boundary } \\
\text { analysis }\end{array}$ & $\begin{array}{l}\text { Blue and } \\
\text { grey WFs }\end{array}$ & $\begin{array}{c}\text { Develop a } \\
\text { new method } \\
\text { that includes }\end{array}$ \\
\hline
\end{tabular}




\begin{tabular}{|c|c|c|c|c|}
\hline $\begin{array}{c}\text { Weng, } \\
\text { Zhang, Deng, } \\
\text { Wang, and Li } \\
\text { (2015) } \\
\text { Eastern Chi- } \\
\text { na }\end{array}$ & & method & & $\begin{array}{l}\text { direct and } \\
\text { indirect } \\
\text { water con- } \\
\text { sumption. }\end{array}$ \\
\hline $\begin{array}{c}\text { Berger, Ent, } \\
\text { Eisner, Bach, } \\
\text { and } \\
\text { Finkbeiner } \\
(2014)\end{array}$ & Industrial & $\begin{array}{l}\text { Water } \\
\text { accounting } \\
\text { and vul- } \\
\text { nerability } \\
\text { evaluation } \\
\text { (WAVE) } \\
\text { and LCA }\end{array}$ & Blue WF & $\begin{array}{l}\text { A new water } \\
\text { accounting } \\
\text { model, } \\
\text { WAVE is } \\
\text { introduced } \\
\text { by consider- } \\
\text { ing the at- } \\
\text { mospheric } \\
\text { evaporation } \\
\text { recycling } \\
\text { and freshwa- } \\
\text { ter depletion. }\end{array}$ \\
\hline $\begin{array}{c}\text { Berger, } \\
\text { Warsen, } \\
\text { Krinke, } \\
\text { Bach, and } \\
\text { Finkbeiner } \\
\text { (2012) } \\
\text { Europe, } \\
\text { South Africa } \\
\text { and Russia }\end{array}$ & $\begin{array}{l}\text { Volkswagen } \\
\text { 's car mod- } \\
\text { els Passat, } \\
\text { Polo, and } \\
\text { Golf }\end{array}$ & $\begin{array}{c}\text { Life Cycle } \\
\text { Inventory } \\
\text { (LCI) and } \\
\text { impact } \\
\text { assess- } \\
\text { ments }\end{array}$ & Blue WF & $\begin{array}{l}\text { Develop a } \\
\text { new method } \\
\text { for manufac- } \\
\text { turing indus- } \\
\text { try by com- } \\
\text { bining sever- } \\
\text { al methods. }\end{array}$ \\
\hline
\end{tabular}

\subsection{Water Footprint Assessment for Food Products}

This section described numerous available models of WFA on food products.

\subsubsection{Water Footprint Assessment on Food Products}

Based on study conducted by Owusu-sekyere, Jordaan, and Chouchane (2017) in South Africa [17], empirical formula was used to quantify the economic water productivities and WF of dairy products. The results showed that the overall WFs in dairy products were greater than the worldwide average total WFs at year 1996 to 2005 . It concluded that the green water should be efficiently utilized to produce dairy food products.

From the study by Murphy et al. (2017) [3], a volumetric WF was determined and impacts for the production of fat-and-protein corrected milk (FPCM) was associated. This study used a total of 24 dairy farms located in Ireland. The results showed that the WF of FPCM production was at an average of $690 \mathrm{~L}$ water $/ \mathrm{kg}$. Water required for pasture production contributed 85 percent to the overall WF, contributed 10 percent to the imported fodder production, contributed 4 percent to the concentrates production and on-farm water used was found to be less than 1 percent.

Bai et al. (2017) [4] used ISO 14046 to analyze the overall WFA for dairy industries in China. The results showed that the major water consumption was from indirect water footprint where different production processes affected different environmental impacts. Miguel, Hoekstra, and García-Calvo (2015) [18] quantified and evaluated blue, green and grey WFs on Spanish pork production. This study found that about half of the water used to produce concentrated feed, originated from Spain. However, the remaining water was used in the imported feedstock products. The comparison between blue and grey WFs on feed production indicated water scarcity and water pollution were mostly from the feed produced in Spain, unlike the imported materials originated from watersheds where freshwater resources are over exploited.

Study by Ene et al. in Romania (2013) [19], determined WFA for $750 \mathrm{~mL} /$ bottle of wine produced. Production-chain diagram was used to show the related processes from raw source to the output product and the environmental impacts, as well as the current emissions, considering the existing equipment and actual water practices. The outcomes of this study showed that almost $99 \%$ of total WF is connected to supply-chain water use, out of which $82 \%$ are green water, $3 \%$ are blue water and $15 \%$ are grey water.
Jefferies et al. (2012) [6] applied LCA and WF approaches to two case studies on production of tea and margarine. Blue and green WF, excluding grey WF, was calculated by using the methodology of operational and supply chain WF. Blue WF is accounted by using LCA inventory. The findings showed that the synergies, similarities and differences at the water quantifying and impact assessment levels for both methods improved and advanced the water resource assessment process.

A comprehensive account of the WF on animal products, considering distinct manufacturing systems and feed composition per country and animal type, is provided by Mekonnen and Hoekstra (2012) [20]. The results presented that from a freshwater perspective, animal products from grazing systems have a smaller blue and grey WF as compared to the goods from manufacturing systems. It is found to be more water-efficient in obtaining fat, calories and protein through crop products than of animal products.

\subsection{Summary of Water Footprint Assessment on Food Products}

Table 2: Summary of water footprint assessment on food products

\begin{tabular}{|c|c|c|c|c|}
\hline $\begin{array}{c}\text { Authors, } \\
\text { year, coun- } \\
\text { try }\end{array}$ & Product & Method & Component & Outcomes \\
\hline $\begin{array}{c}\text { Owusu- } \\
\text { sekyere, } \\
\text { Jordaan, } \\
\text { and } \\
\text { Chouchane } \\
\text { (2017) } \\
\text { South Afri- } \\
\text { ca }\end{array}$ & $\begin{array}{c}\text { Dairy } \\
\text { products }\end{array}$ & $\begin{array}{l}\text { Empirical } \\
\text { formula }\end{array}$ & $\begin{array}{c}\text { Blue, green } \\
\text { and grey } \\
\text { WFs }\end{array}$ & $\begin{array}{l}\text { The results are } \\
\text { compared with } \\
\text { the global } \\
\text { average total } \\
\text { WF. }\end{array}$ \\
\hline $\begin{array}{c}\text { Murphy, } \\
\text { Boer, } \\
\text { Middelaar, } \\
\text { Holden, } \\
\text { Shalloo, } \\
\text { Curran, and } \\
\text { Upton } \\
\text { (2017) } \\
\text { Ireland } \\
\end{array}$ & $\begin{array}{c}\text { Dairy } \\
\text { products }\end{array}$ & & $\begin{array}{l}\text { Blue and } \\
\text { green } \\
\text { WFs }\end{array}$ & $\begin{array}{l}\text { First study that } \\
\text { use specific } \\
\text { farm data to } \\
\text { evaluate the } \\
\text { WF of dairy. }\end{array}$ \\
\hline $\begin{array}{l}\text { Bai, Ren, } \\
\text { Zheng, } \\
\text { Zhou, and } \\
\text { Hu } \\
\text { (2017) } \\
\text { China }\end{array}$ & $\begin{array}{c}\text { Dairy } \\
\text { products }\end{array}$ & ISO 14046 & $\begin{array}{c}\text { Green, blue } \\
\text { and grey } \\
\text { WFs }\end{array}$ & $\begin{array}{c}\text { Method not } \\
\text { only determine } \\
\text { WF, but also } \\
\text { include water } \\
\text { scarcity foot- } \\
\text { print, water } \\
\text { degradation } \\
\text { footprint and } \\
\text { water eutroph- } \\
\text { ication foot- } \\
\text { print. }\end{array}$ \\
\hline $\begin{array}{c}\text { Miguel, } \\
\text { Hoekstra, } \\
\text { and García- } \\
\text { calvo } \\
\text { (2015) } \\
\text { Spanish }\end{array}$ & $\begin{array}{c}\text { Pork } \\
\text { products }\end{array}$ & $\begin{array}{l}\text { WF ac- } \\
\text { counting } \\
\text { proposed } \\
\text { by WFN }\end{array}$ & $\begin{array}{c}\text { Green, blue } \\
\text { and grey } \\
\text { WFs }\end{array}$ & $\begin{array}{l}\text { Provide a } \\
\text { feasible option } \\
\text { to determine } \\
\text { the impact on } \\
\text { environmental. }\end{array}$ \\
\hline $\begin{array}{c}\text { Ene, } \\
\text { Teodosiu, } \\
\text { Robu, and } \\
\text { Volf } \\
(2013) \\
\text { Romania }\end{array}$ & Wine & $\begin{array}{l}\text { Hoekstra } \\
\text { approach }\end{array}$ & $\begin{array}{c}\text { Green, blue } \\
\text { and grey } \\
\text { WFs }\end{array}$ & $\begin{array}{c}\text { Focus on } \\
\text { WFA based on } \\
\text { product-chain } \\
\text { diagram and } \\
\text { provide sug- } \\
\text { gestions of } \\
\text { sustainable } \\
\text { practices. }\end{array}$ \\
\hline $\begin{array}{l}\text { Jefferies, } \\
\text { Munoz, } \\
\text { Hodges, } \\
\text { King, } \\
\text { Aldaya, } \\
\text { Ercin, } \\
\text { Canals, and } \\
\text { Hoekstra } \\
\text { (2012) }\end{array}$ & $\begin{array}{c}\text { Tea and } \\
\text { margarine }\end{array}$ & $\begin{array}{l}\text { Hoekstra } \\
\text { approach } \\
\text { and LCA }\end{array}$ & $\begin{array}{l}\text { Green and } \\
\text { blue WFs }\end{array}$ & $\begin{array}{l}\text { Synergies, } \\
\text { similarities } \\
\text { and differ- } \\
\text { ences at both } \\
\text { the water } \\
\text { accounting } \\
\text { and impact } \\
\text { assessment } \\
\text { levels are }\end{array}$ \\
\hline
\end{tabular}




\begin{tabular}{|c|c|c|c|c|}
\hline World & & & & $\begin{array}{c}\text { identified with } \\
\text { the purpose of } \\
\text { enhancing and } \\
\text { advancing the } \\
\text { water resource } \\
\text { assessment } \\
\text { process. }\end{array}$ \\
\hline $\begin{array}{c}\text { Mekonnen } \\
\text { and } \\
\text { Hoekstra } \\
\text { (2012) } \\
\text { China, } \\
\text { India, } \\
\text { Netherlands } \\
\text { and USA }\end{array}$ & $\begin{array}{c}\text { Farm } \\
\text { animal } \\
\text { products }\end{array}$ & $\begin{array}{c}\text { Hoekstra } \\
\text { approach }\end{array}$ & $\begin{array}{c}\text { Green, blue } \\
\text { and grey } \\
\text { WFs }\end{array}$ & $\begin{array}{c}\text { Provide plenty } \\
\text { data for fur- } \\
\text { ther studies. }\end{array}$ \\
& & & & \\
\hline
\end{tabular}

\section{Water-Food-Energy Nexus}

Water-Food-Energy (WFE) nexus defined three inextricably connected sectors namely water, food and energy. The WFE nexus can be characterized by: i) physical, chemical, and biophysical, ii) resource input-output, and iii) thru institutions, markets, and infrastructure [21]. This ensuing section described various approaches to analyze WFE nexus.

\subsection{Water-Food-Energy Nexus}

Salmoral and Yan (2018) [22] showed the available life cycle inventory (LCI) databases in WFE nexus studies and the possibility of LCA applications from food consumption perspective. This paper aims to quantify the WFE nexus and measured the upstream virtual water; as well as measured the embodied energy flows for food products consumed in a catchment of South West England namely the Tamar catchment. The direct, indirect water used and annual demand on domestic food consumption in the catchment were quantified at $17 \mathrm{hm}^{3}$ of blue water, $244 \mathrm{hm}^{3}$ of green water and $834 \mathrm{TJ}$ of energy, respectively.

Silalertruksa and Gheewala (2018) [23] evaluated the land-waterenergy nexus of various sugarcane production system at two regions in Thailand where the growth of sugarcane is being promoted. From this study, it was found that water use is the significant factor in the management of land-water-energy nexus for sugarcane. The results also showed that the yield of sugarcane has increased by $23-54 \%$ using the current irrigation system. On the other hand, the ecological and carbon footprint are found to decrease.

Based on study by Danilo et al. (2018) [24], the green and blue water requirements are determined to link the harvested land and water appropriations for rubber production. The results showed approximately 136 to $149 \times 10^{9} \mathrm{~m}^{3} \mathrm{y}^{-1}$ of freshwater are needed for rubber production at over 10 million ha of rich land. If these sources were replacing to rice production, it would be more sufficient to provide enough food in order to decrease the problem of malnourishment.

Endo et al. (2017) [25] determined a systematic mathematical modelling-based approach to review and analyse the connection between WFE nexus at the study area, nexus keywords and investors in order to measure the present state of nexus. The study area is separated into Asia, Africa, Europe, Middle East, Oceania, South America and North America. The results showed that Africa has less concentrate on water-energy (7\%), but North America and Oceania were inclined to concentrate on a selected nexus sort with water-energy (46\%) and climate (43\%).

Kurle et al. (2016) [26] proposed a framework in the context of water-energy nexus for multi-level simulation as well as recommendations for model coupling and knowledge exchange. The study showed that the water for energy and energy for water and have totalled to share $69 \%$ of the entire energy demand and to $54 \%$ of the costs and environmental impact.

Yuling et al. (2016) [27] proposed a systematic mathematical modelling-based approach to design the local water-food-energy
(WFE) nexus. This study was conducted at a UK eco-town. The results established the benefits of an integrated design of a system making use of native resources to fulfill its demands and available centralized provisions, while not considering integration opportunities between subsystems.

Kumar et al. (2015) [28] analyzed the WFE nexus on breakfast cereals and snacks manufactured by Kellogg Europe, the world's largest cereal producer. The study was carried out using LCA to integrate the environmental sustainability considerations into the process of production. The results showed that the main contributor of energy consumption is at the manufacturing stage. However, over $90 \%$ of WF was influenced by its food ingredients.

\subsection{Summary of Water-Food-Energy Nexus}

\begin{tabular}{|c|c|c|c|}
\hline $\begin{array}{l}\text { Authors, year, } \\
\text { country }\end{array}$ & Method & Parameter & Outcomes \\
\hline $\begin{array}{c}\text { Salmoral and } \\
\text { Yan } \\
(2018) \\
\text { South West } \\
\text { England }\end{array}$ & $\begin{array}{l}\text { LCA, LCI and } \\
\text { system bound- } \\
\text { ary approach }\end{array}$ & $\begin{array}{l}\text { Virtual water, } \\
\text { energy con- } \\
\text { sumption and } \\
\text { virtual nutrient }\end{array}$ & $\begin{array}{l}\text { The first study } \\
\text { tried to guide the } \\
\text { physical WFE } \\
\text { nexus in Tamar } \\
\text { catchment and } \\
\text { expose the energy } \\
\text { and water } \\
\text { hotspots for food } \\
\text { using LCA. }\end{array}$ \\
\hline $\begin{array}{c}\text { Silalertruksa } \\
\text { and Gheewala } \\
(2018) \\
\text { Thailand }\end{array}$ & $\begin{array}{c}\text { LCA and } \\
\text { system bound- } \\
\text { ary approach }\end{array}$ & $\begin{array}{l}\text { Carbon, eco- } \\
\text { logical and } \\
\text { water scarcity } \\
\text { footprints }\end{array}$ & $\begin{array}{l}\text { The sugarcane } \\
\text { yields are in- } \\
\text { creased with } \\
\text { irrigation system } \\
\text { and increase the } \\
\text { energy consump- } \\
\text { tion as well. The } \\
\text { ecological and } \\
\text { carbon footprints } \\
\text { of sugarcane are } \\
\text { decreased due to } \\
\text { the efficient irri- } \\
\text { gation system. }\end{array}$ \\
\hline $\begin{array}{l}\text { Danilo, Rosa, } \\
\text { Cristina, and } \\
\text { Odorico } \\
\text { (2018) } \\
\text { Bangladesh, } \\
\text { Cambodia, } \\
\text { China, India, } \\
\text { Indonesia, Lao } \\
\text { PDR, Malay- } \\
\text { sia, Myanmar, } \\
\text { Philippines, Sri } \\
\text { Lanka, Thai- } \\
\text { land and Vi- } \\
\text { etnam }\end{array}$ & $\begin{array}{l}\text { WFN and } \\
\text { conceptual } \\
\text { framework }\end{array}$ & $\begin{array}{l}\text { WF, land use } \\
\text { and food de- } \\
\text { mand }\end{array}$ & $\begin{array}{l}\text { The results } \\
\text { showed that the } \\
\text { production of } \\
\text { natural rubber } \\
\text { need to use large } \\
\text { water volume due } \\
\text { to high evapotran- } \\
\text { spiration rates. It } \\
\text { also showed that } \\
\text { rubber production } \\
\text { has significant } \\
\text { environmental, } \\
\text { economic, and } \\
\text { social impacts. }\end{array}$ \\
\hline $\begin{array}{l}\text { Endo, Tsurita, } \\
\text { Burnett, and } \\
\text { Orencio } \\
\text { (2017) } \\
\text { Asia, Africa, } \\
\text { Europe, Mid- } \\
\text { dle East, Oce- } \\
\text { ania, South } \\
\text { America and } \\
\text { North America }\end{array}$ & & & $\begin{array}{l}\text { A review paper } \\
\text { that identified } \\
\text { four types of } \\
\text { nexus research: } \\
\text { WFE, water- } \\
\text { energy, water- } \\
\text { food, and climate } \\
\text { linked. Total } 37 \\
\text { projects have been } \\
\text { selected to review } \\
\text { and analyze the } \\
\text { WFE nexus. }\end{array}$ \\
\hline $\begin{array}{c}\text { Kurle, } \\
\text { Herrmann, } \\
\text { Thiede, and } \\
\text { Sch } \\
(2016)\end{array}$ & $\begin{array}{c}\text { LCA, WFA } \\
\text { and multi-level } \\
\text { simulation }\end{array}$ & $\begin{array}{l}\text { Water demand, } \\
\text { power demand } \\
\text { and heat emis- } \\
\text { sion }\end{array}$ & $\begin{array}{l}\text { A multi-level } \\
\text { simulation model } \\
\text { framework for } \\
\text { factories is pro- } \\
\text { posed and ap- } \\
\text { plied to a water- } \\
\text { energy nexus } \\
\text { case study. The } \\
\text { framework al- } \\
\text { lows the deep }\end{array}$ \\
\hline
\end{tabular}




\begin{tabular}{|c|c|c|c|}
\hline & & & $\begin{array}{c}\text { analysis of en- } \\
\text { hancement } \\
\text { measures and } \\
\text { interdependences. }\end{array}$ \\
\hline $\begin{array}{l}\text { Yuling, Pah, } \\
\text { Martinez- } \\
\text { hernandez, } \\
\text { Leach, and } \\
\text { Yang } \\
\text { (2016) } \\
\text { UK }\end{array}$ & $\begin{array}{l}\text { LCA and sys- } \\
\text { tematic math- } \\
\text { ematical mod- } \\
\text { elling-based } \\
\text { approach }\end{array}$ & $\begin{array}{c}\text { Energy and } \\
\text { water sources, } \\
\text { electricity, heat } \\
\text { and water } \\
\text { consumption, } \\
\text { and food de- } \\
\text { mand }\end{array}$ & $\begin{array}{l}\text { This paper pro- } \\
\text { posed a method- } \\
\text { ology and a } \\
\text { mathematical } \\
\text { model that pro- } \\
\text { duced superior } \\
\text { results to solve } \\
\text { the problem of } \\
\text { local demands in } \\
\text { a UK eco-town. } \\
\text { This approach } \\
\text { only concentrates } \\
\text { on designing a } \\
\text { local production } \\
\text { system from } \\
\text { scratch. }\end{array}$ \\
\hline $\begin{array}{c}\text { Kumar, } \\
\text { Burkinshaw, } \\
\text { and Azapagic } \\
(2015) \\
\text { Europe }\end{array}$ & LCA and WFN & $\begin{array}{c}\text { Ingredients, } \\
\text { electricity, gas } \\
\text { and water } \\
\text { demand, and } \\
\text { waste }\end{array}$ & $\begin{array}{l}\text { This study in- } \\
\text { cluded the envi- } \\
\text { ronmental sus- } \\
\text { tainability in the } \\
\text { WFE nexus of } \\
\text { breakfast cereals } \\
\text { and snacks by } \\
\text { evaluating the } \\
\text { LCA. Most ener- } \\
\text { gy consumption } \\
\text { is occurred dur- } \\
\text { ing manufactur- } \\
\text { ing stage while } \\
\text { the WF of ingre- } \\
\text { dients is more } \\
\text { than } 90 \% \text {. }\end{array}$ \\
\hline
\end{tabular}

\section{Discussion}

Total 9 papers of water footprint of industrial products are included in Table 1 and 7 papers of the food products are included in Table 2. Of the 16 previous studies about water footprint of industrial and food productions, 5 studies analyzed on green, blue and grey water footprints; 5 studies accounted the blue and grey water footprints while 3 aimed at studying the green and blue water footprints; 2 studies determined blue water footprint only; 1 more aimed at accounting water scarcity footprint. Blue WF was accounted in all of them, while only in $62.5 \%$ of papers assessed grey water footprint and 50\% authors took green water footprint into quantify. The results showed that the percentage of reviewed papers studied at local or geographical area is $56.25 \%$, whereas the remaining $43.75 \%$ were conducted on a global extent.

There are various methods to determine WFA. However, the simple numerical sum of green water is not included in the manufacturing process since it may not usually be utilized by industrial facilities except when rainwater harvesting system is practiced $[2,9,14,15,17]$. From previous studies $[9,16]$, the results showed that several methods of LCA and WFN can efficiently be combined to obtain the sufficient results. Method [15] that considered recycled of atmospheric evaporation and fresh water depletion can help to explain the values of water footprint well.

From the total 7 reviewed papers of WFE nexus as shown in Table 3, 4 papers evaluated WFE nexus; 2 studies determined waterenergy nexus while 1 more aimed at identifying water-food nexus. All of them used WFN to account the water footprint, while $85.71 \%$ of papers analyzed the WF by combining the LCA and WFN.

The previous studies by $[22,23,25,26,27,28]$ showed that WFE nexus can be evaluated using LCA in order to determine the environmental impacts. The required parameters vary according to the impact assessments to be determined.

From the previous studies that have been reviewed, it is suggested to combine the approaches of LCA and WFN for evaluating WFA and WFE nexus of electronic and food products. The various approaches used to determine WFA and WFE nexus at different industrial products varied. Each approach provides advantages and limitations such as database, tool, and accuracy. It is significant to select the most suitable method explicitly for specific products to accomplish accurate results.

\section{Conclusion}

This study reviews WFA on electronic and food manufacturing products at various optimization methods, as well as its WFE nexus. Based on these discussions, the relationship between water footprint, food and energy are pertinent. The positive and negative impacts of industrial products on manufacturing processes chain can be identified from the WFA conducted. In short, the environmental indicators on WF must clearly be supported by scientific evidences.

\section{Acknowledgement}

This study is sponsored by Universiti Tenaga Nasional - Bold Scholarship 2017/18.

\section{References}

[1] OECD, Environmental Outlook to 2050: The Consequences of Inaction, Organisation for Economic Co-operation and Development, Paris, France, 2012

[2] S. M. Hosseinian and R. Nezamoleslami, "Water Footprint and Virtual Water Assessment in Cement Industry: A Case Study in Iran,” J. Clean. Prod., vol. 172, pp. 2454-2463, 2017.

[3] E. Murphy, I. J. M. de Boer, C. E. van Middelaar, N. M. Holden, L. Shalloo, T. P. Curran, and J. Upton, "Water footprinting of dairy farming in Ireland,” J. Clean. Prod., vol. 140, pp. 547-555, 2017.

[4] X. Bai, X. Ren, N. Z. Khanna, N. Zhou, and M. Hu, "Comprehensive water footprint assessment of the dairy industry chain based on ISO 14046: A case study in China," Resour. Conserv. Recycl., vol. 132, no. August 2017, pp. 369-375, 2017.

[5] Y. Yu, K. Hubacek, K. Feng, and D. Guan, "Assessing regional and global water footprints for the UK," Ecol. Econ., vol. 69, no. 5, pp. 1140-1147, 2010.

[6] D. Jefferies, I. Muñoz, J. Hodges, V. J. King, M. Aldaya, A. E. Ercin, L. Milà I Canals, and A. Y. Hoekstra, "Water footprint and life cycle assessment as approaches to assess potential impacts of products on water consumption. Key learning points from pilot studies on tea and margarine," J. Clean. Prod., vol. 33, pp. 155-166 2012.

[7] S. A. Munro, G. C. G. Fraser, J. D. Snowball, and M. Pahlow, "Water footprint assessment of citrus production in South Africa: A case study of the Lower Sundays River Valley," J. Clean. Prod., vol. 135 , pp. 668-678, 2016.

[8] A. Y. Hoekstra, A. K. Chapagain, and M. M. Aldaya, The Water Footprint Assessment Manual. 2011.

[9] P. W. Gerbens-Leenes, A. Y. Hoekstra, and R. Bosman, "The blue and grey water footprint of construction materials: Steel, cement and glass," Water Resour. Ind., vol. 19, no. April 2017, pp. 1-12, 2018.

[10] M. A. Shaikh, M. Kucukvar, N. Cihat, and G. Kirkil, “A framework for water and carbon footprint analysis of national electricity production scenarios," Energy, vol. 139, pp. 406-421, 2017.

[11] J. F. Schyns, M. J. Booij, and A. Y. Hoekstra, "The water footprint of wood for lumber, pulp, paper, fuel and firewood," Adv. Water Resour., vol. 107, pp. 490-501, 2017.

[12] C. Musikavong and S. H. Gheewala, "Water scarcity footprint of products from cooperative and large rubber sheet factories in southern Thailand," J. Clean. Prod., vol. 134, no. Part B, pp. 574$582,2016$.

[13] L. Scherer and S. Pfister, "Global water footprint assessment of hydropower," vol. 99, pp. 711-720, 2016.

[14] Y. Gu, J. Xu, A. A. Keller, D. Yuan, Y. Li, B. Zhang, Q. Weng, X. Zhang, P. Deng, H. Wang, and F. Li, "Calculation of water footprint of the iron and steel industry: a case study in Eastern China," vol. 92, pp. 274-281, 2015. 
[15] M. Berger, R. Ent, S. Eisner, V. Bach, and M. Finkbeiner, "Water accounting and vulnerability evaluation (WAVE): Considering atmospheric evaporation recycling and therisk of freshwater depletion in water footprinting," no. March, 2014.

[16] M. Berger, J. Warsen, S. Krinke, V. Bach, and M. Finkbeiner, "Water footprint of European cars: Potential impacts of water consumption along automobile life cycles," vol. 46, pp. 4091-4099, 2012.

[17] E. Owusu-Sekyere, H. Jordaan, and H. Chouchane, "Evaluation of water footprint and economic water productivities of dairy products of South Africa," Ecol. Indic., vol. 83, no. September 2016, pp. $32-$ 40, 2017.

[18] Á. De Miguel, A. Y. Hoekstra, and E. García-Calvo, "Sustainability of the water footprint of the Spanish pork industry," Ecol. Indic., vol. 57, pp. 465-474, 2015.

[19] S. A. Ene, C. Teodosiu, B. Robu, and I. Volf, "Water footprint assessment in the winemaking industry: A case study for a Romanian medium size production plant," J. Clean. Prod., vol. 43, pp. 122-135, 2013.

[20] M. M. Mekonnen and A. Y. Hoekstra, "A Global Assessment of the Water Footprint of Farm Animal Products," Ecosystems, vol. 15, no. 3, pp. 401-415, 2012.

[21] X. Cai, K. Wallington, M. Sha, and L. Marston, "Advances in Water Resources Understanding and managing the food-energywater nexus - opportunities for water resources research," vol. 111, no. April 2017, pp. 259-273, 2018.

[22] G. Salmoral and X. Yan, "Resources , Conservation \& Recycling Food-energy-water nexus: A life cycle analysis on virtual water and embodied energy in food consumption in the Tamar catchment, UK," no. January, 2018.

[23] T. Silalertruksa and S. H. Gheewala, "Land-water-energy nexus of sugarcane production in Thailand," vol. 182, pp. 521-528, 2018.

[24] D. Danilo, L. Rosa, M. Cristina, and P. D. Odorico, "The waterland-food nexus of natural rubber production," vol. 172, 2018.

[25] A. Endo, I. Tsurita, K. Burnett, and P. M. Orencio, "Journal of Hydrology: Regional Studies A review of the current state of research on the water, energy, and food nexus," vol. 11, pp. 20-30, 2017.

[26] D. Kurle, C. Herrmann, S. Thiede, and M. Sch, "Multi-level simulation in manufacturing companies: The water- energy nexus case," vol. 139, pp. 1118-1127, 2016.

[27] M. Yuling, L. Pah, E. Martinez-hernandez, M. Leach, and A. Yang, "Designing integrated local production systems: A study on the food- energy-water nexus," vol. 135, 2016.

[28] H. Kumar, R. Burkinshaw, and A. Azapagic, "Environmental sustainability issues in the food - energy - water nexus : Breakfast cereals and snacks," vol. 2, no. January, pp. 17-28, 2015. 